\title{
Subsurface Sedimentary Thickness and Structural types of Formations in Imo State, Nigeria, from Airborne Gravity Data
}

\author{
Peter Ogochuku Eke ${ }^{1 *} \&$ Stanley Kaubari Nelson ${ }^{2}$ \\ ${ }^{I}$ Reader, Department of Physics, Ignatius Ajuru University of Education, Port Harcourt, Nigeria. \\ ${ }^{2}$ Post Graduate Student, Ajuru University of Education, Port Harcourt, Nigeria. \\ Corresponding Author Email: peter.eke@iaue.edu.ng ${ }^{l^{*}}$
}

DOI: http://doi.org/10.38177/AJBSR.2021.3406

Copyright: ( ) 2021 Peter Ogochuku Eke \& Stanley Kaubari Nelson. This is an open access article distributed under the terms of the Creative Commons Attribution License, which permits unrestricted use, distribution, and reproduction in any medium, provided the original author and source are credited.

\section{ABSTRACT}

\begin{abstract}
Imo State is part of the Niger Delta of Nigeria that is blessed with a lot of natural resources. These have not been fully exploited and subsurface information of the region is needed to enhance the exploration of these resources. In this work airborne gravity data obtained from the Nigerian Geological Survey Agency has been interpreted to obtain information on the structural types, sedimentary thickness and hydrocarbon potentials of the state. These were archived by use of Oasis Montaj software. The residual gravity anomaly was first extracted from the field data with a polynomial operation and then enhanced by a high pass filter before gridding, modelling and depth estimation, using inverse and forward modelling and Euler deconvolution operation. The results reveal syncline and anticline structures with strike angles of varying degrees and strike-slip faults. The depth to evaluated anomalous bodies was between 4,001 $\mathrm{m}$ and 9,439 $\mathrm{m}$, all located in the Ameki and Imo Formations which are composed of sandstones and shales. The structures and formations they occur are favorable environments for hydrocarbon habitation as is common in the Niger delta basin. The Euler depth estimates gave sedimentary thickness ranges of $113.5 \mathrm{~m}$ to 8,717 $\mathrm{m}$ and falls within basement depths in the Niger Delta. Keywords: Sedimentary thickness, Syncline structures, Anticline structures, Basement depth, Gravity data.
\end{abstract}

\section{Introduction}

Imo state is among the states that make up the region referred to as the Niger delta of Nigeria, although, not all parts of it are deltaic in nature. The Niger delta is one of the major basins in Nigeria and is rich with several mineral resources [1], although, more attention is focused on the exploration of hydrocarbon resources in the region. For this reason a lot of geophysical exploratory actives have taken place and is still on going in the region [2] to explore and exploit these resources. Ideally a geophysical exploration aims at obtaining information on the structure, stratigraphy and content of a subsurface using data from different measured parameters [3].

As explained by Biswas and Sharma [4] there are different exploratory geophysical methods based on the measured physical Earth parameter with all methods classified as either natural or artificial energy source methods. Among the natural energy source methods is the gravity method, a potential method, which uses the precise measurement and interpretations of minute variations in the earth's gravitational field from point to point for structural and stratigraphic studies, engineering and environmental applications, location of shallow subsurface voids, faults, ores, basin fills, intrusions and other geologic features including determination of thickness of soil layers [5].

The method has also been used to identify potential hydrocarbon reservoirs [6]. The method, based on Newton's law of graviton, is an indirect means of determining the density of subsurface materials from the Earth's gravitational field with the gravity values being proportional to the density of the subsurface rocks beneath the points of target. For two different materials, there will be a density contrast which with other information can be used for subsurface interpretations. The Niger delta region accounts for over $2.2 \%$ of estimated world reserve of hydrocarbon with a maximum crude oil production capacity of 2.5 million barrels per day and over 206 trillion 
cubic feet of gas. It is also ranked as Africa's largest producer of crude oil and the sixth largest crude oil producing country in the world in the year 2020 [7]. The exploration activity in this region is high especially with seismic activities that have affected the environment a lot. Despite these challenges, exploratory activities are still on going in the region as more subsurface information of the region are sort to fully exploit these resources.

To improve on the available subsurface information in this region, airborne gravity data from a survey in the region is analyzed quantitatively to obtain information on structural types, sedimentary thickness and hydrocarbon potential of Imo State. The gravity method as explained by Eke et al. [2] has advantages and can give information at greater depths that include sedimentary thickness, structural types and structural trending.

\section{Location and Geology of Study Area}

Imo State is southeast of Nigeria transiting from the Niger Delta Basin to the Afikpo Basin [8]. It is bordered on the East by Abia State, River Niger and Delta State on the West, Anambra State on the North and Rivers State on the South. The state lies within latitudes $4^{\circ} 45^{\prime} \mathrm{N}$ and $7^{\circ} 15^{\prime} \mathrm{N}$, and longitude $6^{\circ} 50^{\prime} \mathrm{E}$ and $7^{\circ} 25^{\prime} \mathrm{E}$ with an area of about 5,100 square kilometer. Rainy season begins in April to October with varying annual rainfall of between 1,500 mm and 2,200 mm; average annual temperature of $20^{\circ} \mathrm{C}$ and relative humidity of $75 \%$. This humidity can reach $90 \%$ in the rainy season. The dry season experiences two months of Harmattan from late December to late February. The hottest months are between January and March.

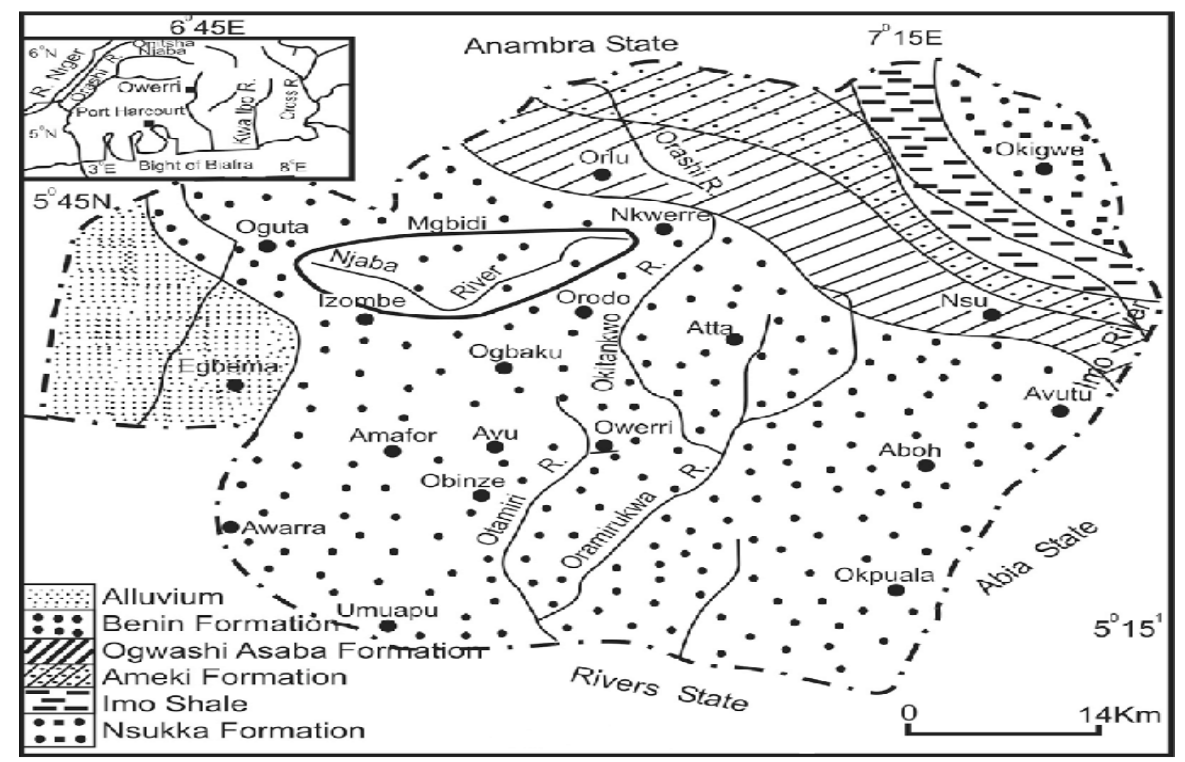

Fig.1. Location and Stratigraphy of the study area from Ahiarakwem \& Onyekwuru [9]

As cited by Eke et al. [2]; Eke [10] and Kamayou [11]; the Niger delta is made up of three major formations. The formations which are late Eocene to the Tertiary in age are composed of clastic sediments of friable sands with intercalations of clayey-shale lenses and isolated units of gravels, conglomerates, very coarse sands and sandstones. The Formations in terms of layering from the earliest formed (bottom) to latest (top) are, the Akata Formation (composed mostly of marine origin and the major hydrocarbon source rock), the Agbada Formation (characterized by shales and sands and is the hydrocarbon bearing and reservoir rock) and the Benin Formation (characterized by sands and non-hydrocarbon bearing). The formations are characterized by sync/post-sedimentary structural styles 
of; rollover anticlines, hanging-walls, foot-walls, back to back structures that affect hydrocarbon migration and trapping in the basin as cited by Kamayou [11]. These formations can be mapped northward of the Niger Delta to the Afikpo and Anambara Basins where the hydrocarbon generating Akata Formation is equivalent to the Imo Formation; the reservoir-containing Agbada Formation transforms to the Ameki Formation and the Benin Formation to the Ogwashi Asaba Formation [12].

In terms of sedimentation, the Ameki Formation begins with a succession of fine to coarse-grained tidally influenced fluvial and fluvial sandstones and passes upward through intercalations of clay, shale and limestone, to coarse-grained cross-bedded sandstones and clays. According to Nwajide [12] the Imo Formation-Ameki Formation contact is marked by the transition from fossiliferous/calcareous shore face facies at the upper levels of the Imo Formation, to the overlying coarse grained tidally-influenced fluvial sandstones that dominate the base of the Ameki Formation. These formations contain several natural minerals as crude oil, natural gas, lead, Calcium Carbonate and zinc.

\section{Materials and Methods}

Fibre Digitized high resolution airborne gravity data obtained from the Nigerian Geological Survey Agency (NGSA) Abuja was used for this study. The data was collected by Fugro Airborne Survey Limited in 2010 with the purpose of assisting and promoting mineral exploration in Nigeria and was collected at $1 \mathrm{~km}$ and $4 \mathrm{~km}$ line spacing with terrain clearance of $80 \mathrm{~m}$.

The regional anomaly (Equation 1) was removed from the corrected field data to obtain the residual anomaly using a second order polynomial least square method [13]

$g_{R}=a_{o}+a_{1} x+a_{2} x^{2}+\cdots \ldots \ldots \ldots a_{n} x^{n}$

Random gridding $[14,15]$ was applied to the residual data to produce a minimum curvature surface to fit the data points. High pass filter [16] of order one was applied to the data to enhance the residual anomalies. This was used to produce Bouguer gravity base map of the state. Selected portions of the base map were modelled for the structural types, depth of occurrence and density information of formations and used to infer probable hydrocarbon reservoirs at various depths. Sedimentary thickness and basement depths across the state were obtained using the Euler deconvolution method [17].

$\left(x-x_{o}\right) \frac{\partial T}{\partial x}+\left(y-y_{o}\right) \frac{\partial T}{\partial y}+\left(z-z_{o}\right) \frac{\partial T}{\partial z}=\eta\left(T-g_{R}\right)$

Where $T_{\left(x_{o}, y_{o}, z_{o}\right)}$ is the gravity source for a total field detected at $T_{(x, y, z)}$ with regional anomaly of $g_{R}$ using a structural index of $\eta$. All analysis and interpretation were achieved with Oasis Montaj software menus.

\section{Results}

Optimum The contoured Bouguer gravity base map, at intervals of $5 \mathrm{mGal}$, for the state is shown in Figure 2a, while Figure $2 \mathrm{~b}$ indicates the modelled points for structural information. The results reveal that the Bouguer gravity values are between $-30.2 \mathrm{mGal}$ to $19.0 \mathrm{mGal}$ within the state with gravity lows more in northwest, southwest and western parts of the state and gravity highs in the northwestern and central parts of the state. 


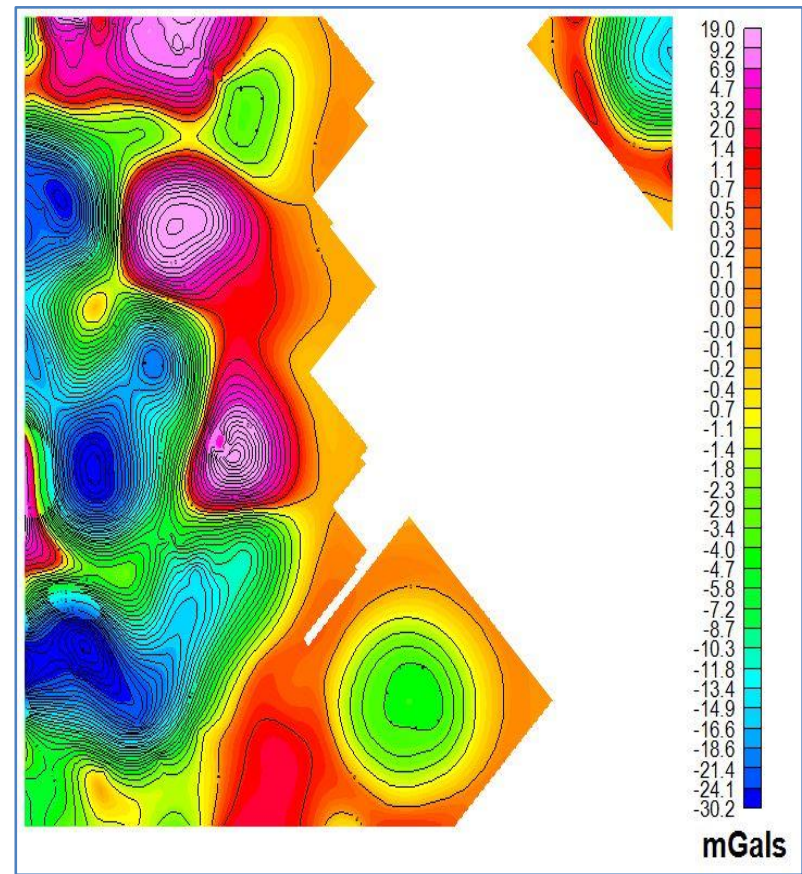

(a)

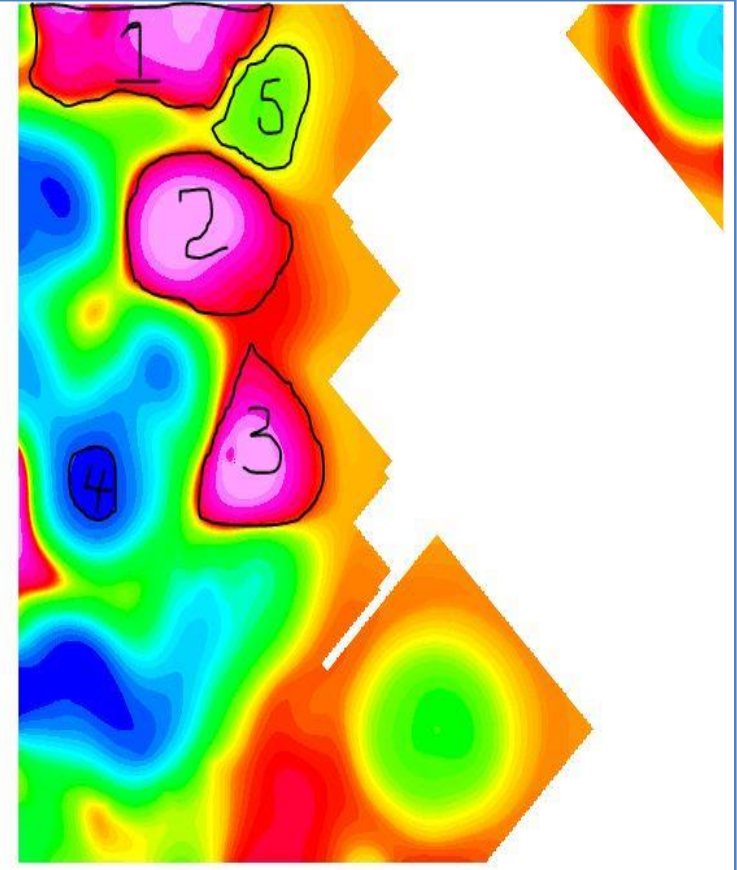

(b)

Fig.2. Bouguer Contour Map of the state and modelled points $(a, b)$

The modelled points, M1, M2, M3, M4 and M5 results are shown in Figures 3 to 8 . The blue lines are the fit to the theoretical models depicted in red lines. The summary results of the models indicate that all structures have dipping angle of 0 , except for M1 with dip of 2.8 degrees, however, the models show strike angles of varying degrees. Faults were observed at varying degrees of strikes for Model 1 at 34.4.degrees, Model 2 at 5.2 degrees, Model 3 at 6.4 degrees, and Model 4 at 9.1 degrees, and Model 5 at 34.6 degrees. Faulted anticlines were observed on Model 1, Model 2, and Model 5 while synclines were observed on Model 3 and Model 4. This structure produces a broad maximum gravity anomaly indicating the area extent of the entire uplifted section. The models indicate that the faults trends evenly E-W and N-S directions.
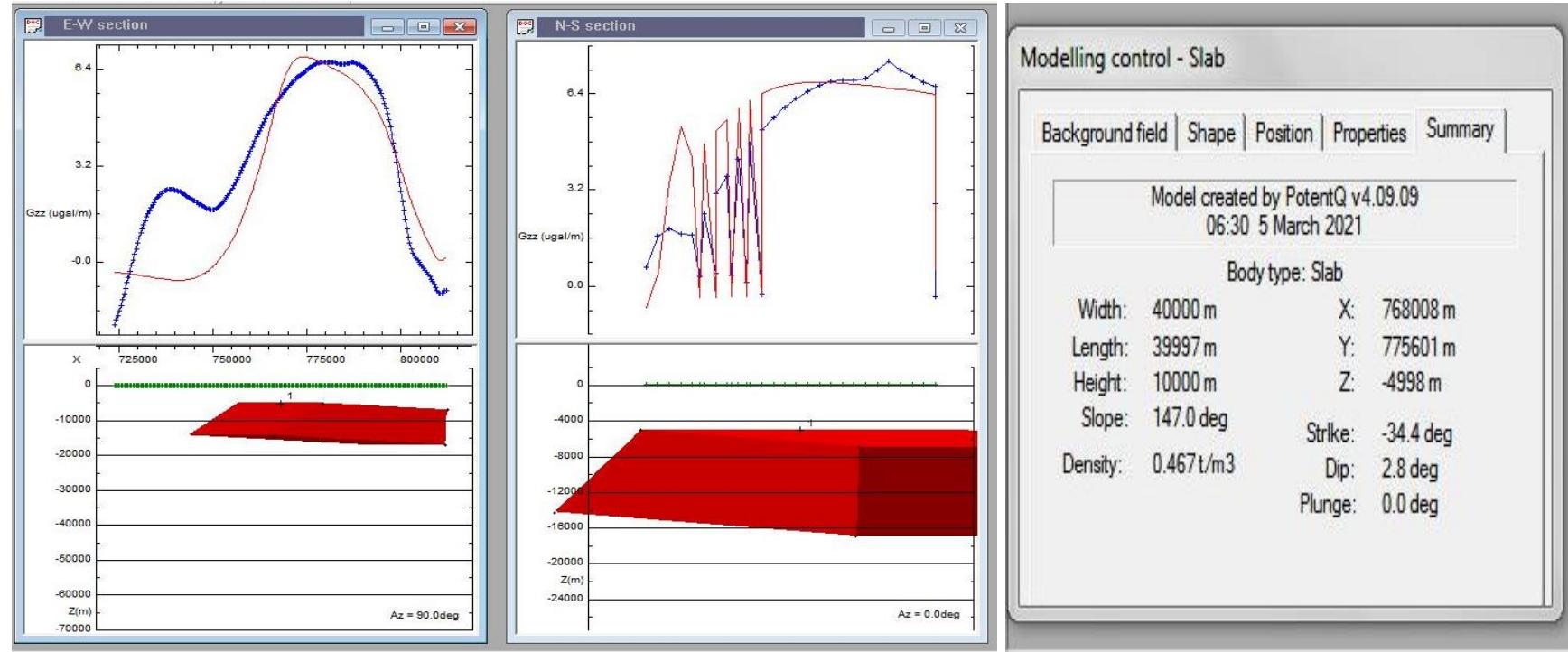

Fig.3. Model results for point M1 


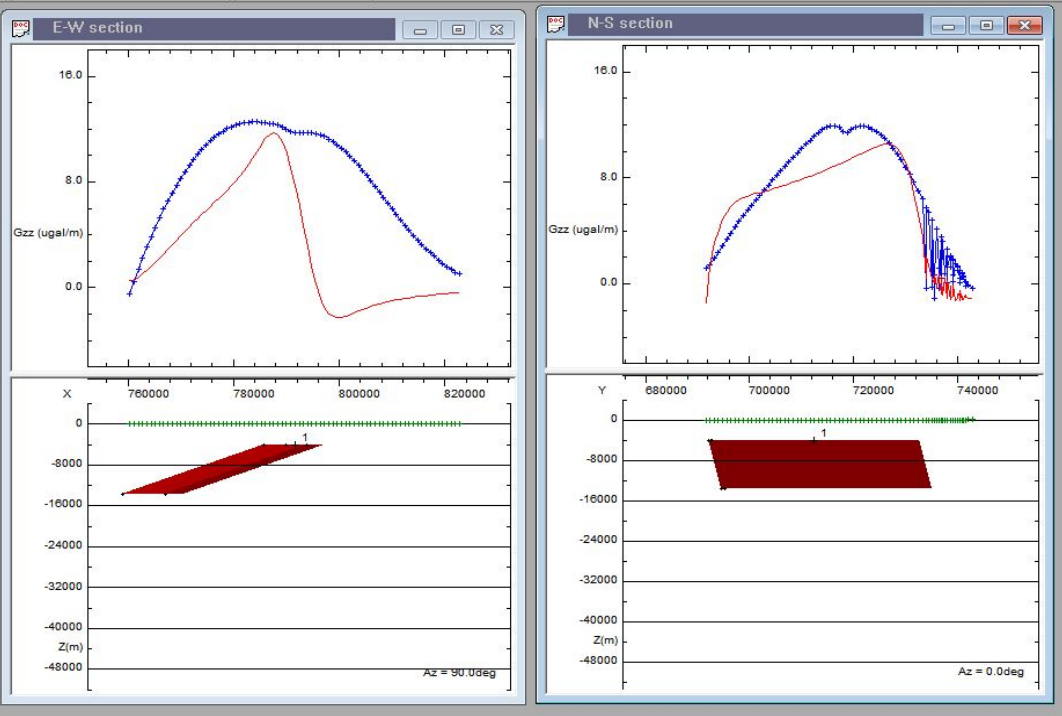

Modelling control - Dyke

Background field $\mid$ Shape $\mid$ Postion $\mid$ Properties Summary

Model created by PotentQ v4.09.09 $08: 465$ March 2021

Bodytype: Dyke

$\begin{aligned} \text { Width: } & 7999 \mathrm{~m} & \text { X: } & 791600 \mathrm{~m} \\ \text { Lenghth: } & 40000 \mathrm{~m} & \text { Y: } & 712400 \mathrm{~m} \\ \text { Height: } & 9651 \mathrm{~m} & \text { Z: } & -4001 \mathrm{~m} \\ \text { Slope: } & 160.2 \mathrm{deg} & \text { Strke: } & 5.2 \mathrm{deg} \\ \text { Density: } & 1.728 \mathrm{t} / \mathrm{m} 3 & \text { Dip: } & 0.0 \mathrm{deg} \\ & & \text { Plunge: } & 0.0 \mathrm{deg}\end{aligned}$

Fig.4. Model results for point M2
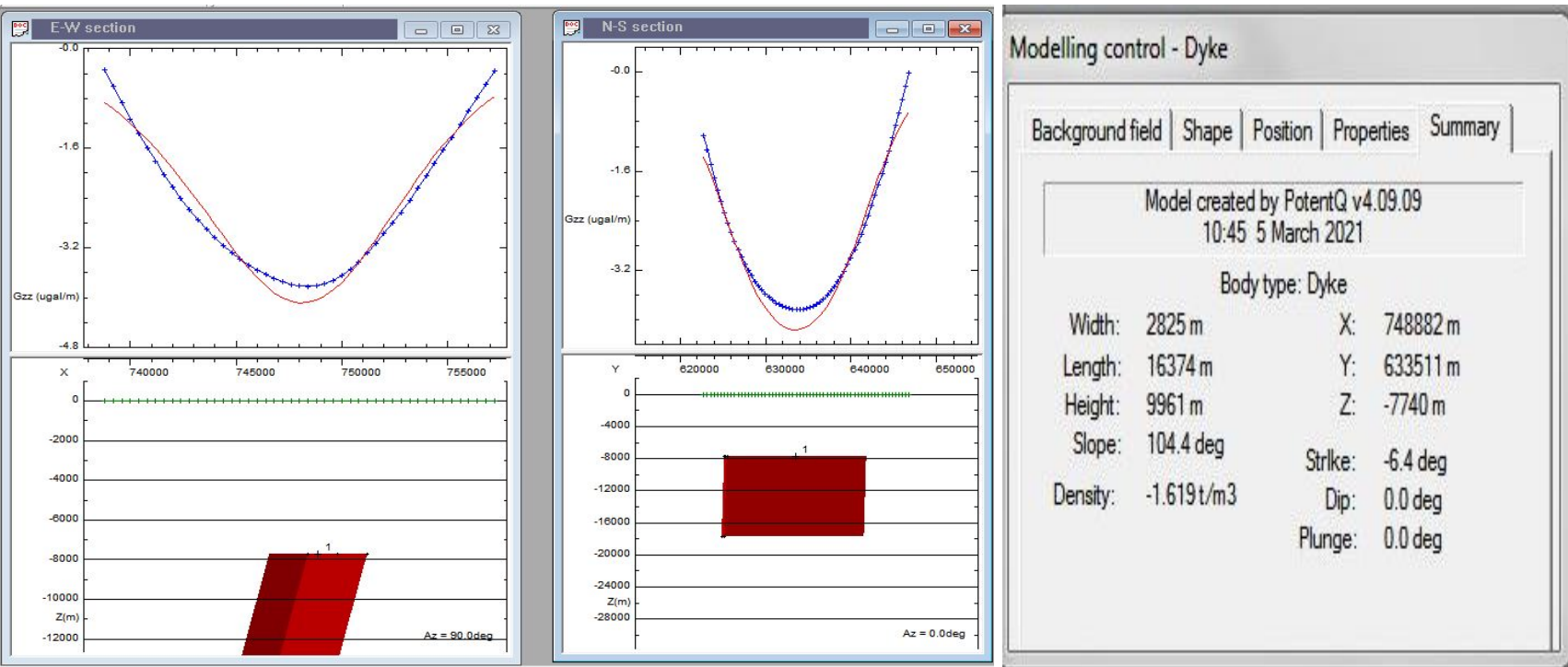

Fig.5. Model results for point M6
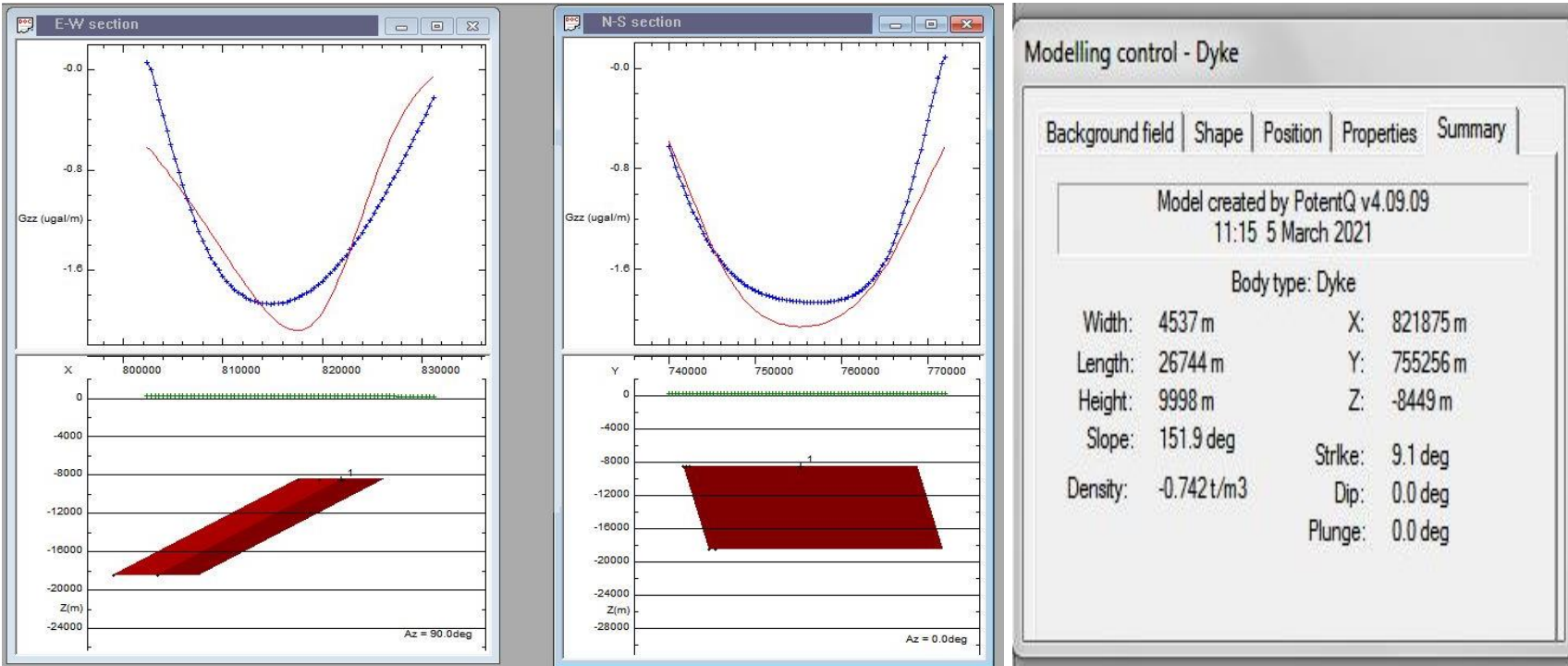

Fig.6. Model results for point M5 


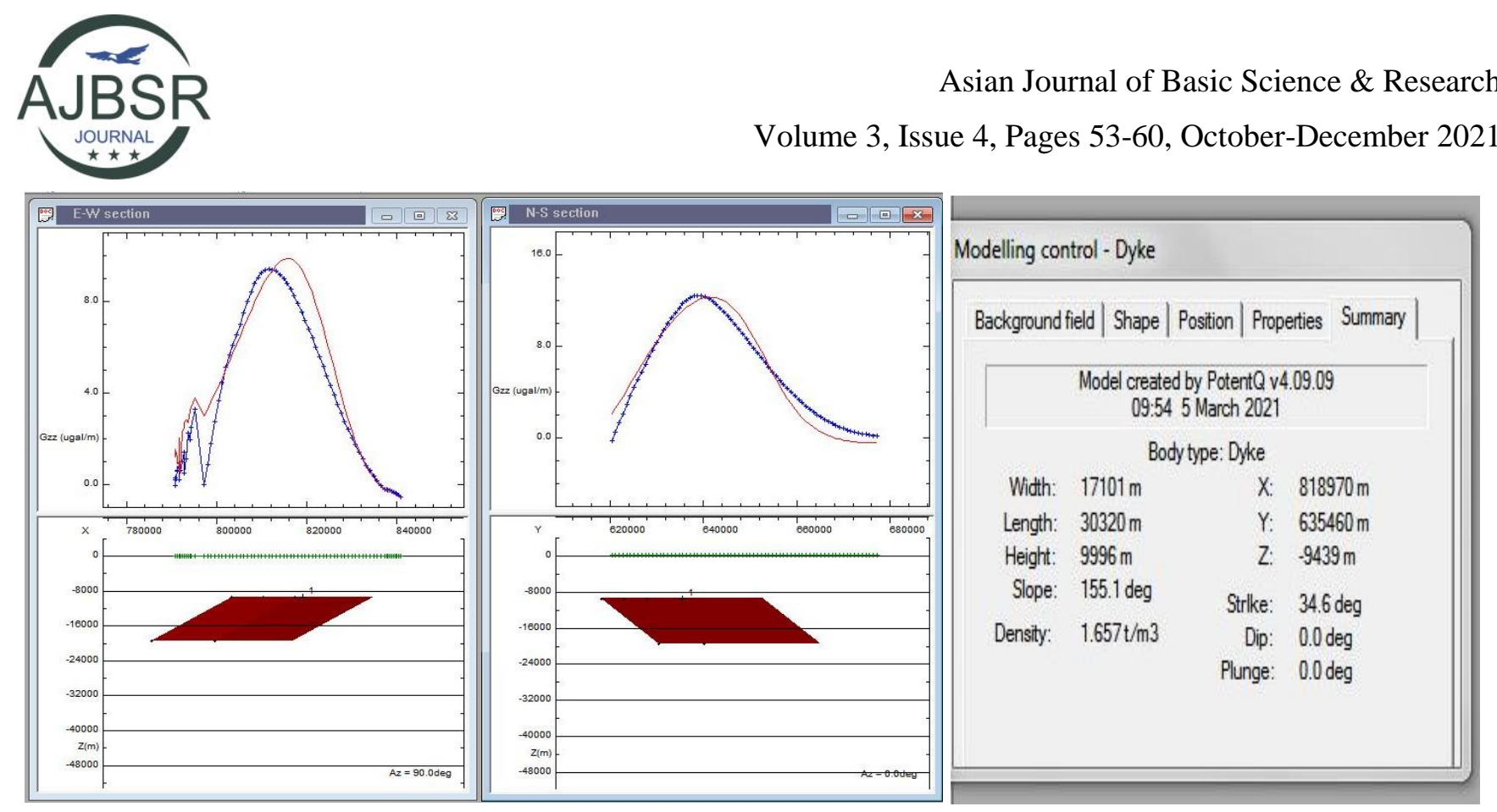

Fig.7. Model results for point M3

Table 1 is a summary of the modelled results while the Euler depth estimate map is shown in Figure 9.

Table 1. Summary Results of Modelled Points

\begin{tabular}{|c|c|c|c|c|}
\hline & $\begin{array}{c}\text { Depth to anomalous } \\
\text { bodies (m) }\end{array}$ & $\begin{array}{c}\text { Density of the } \\
\left.\text { body } \mathbf{( g / \mathbf { c m } ^ { 3 }}\right)\end{array}$ & Model Shape & $\begin{array}{c}\text { Possible cause of the } \\
\text { anomaly }\end{array}$ \\
\hline M1 & 4998 & 0.467 & Slab & \\
\hline M2 & 4001 & 1.728 & Dyke & Sandstone/Shale \\
\hline M3 & 9439 & 1.657 & Dyke & Sandstone/Shale \\
\hline M4 & 7740 & 1.619 & Dyke & Sandstone/Shale \\
\hline M5 & 8449 & 0.742 & Dyke & \\
\hline
\end{tabular}

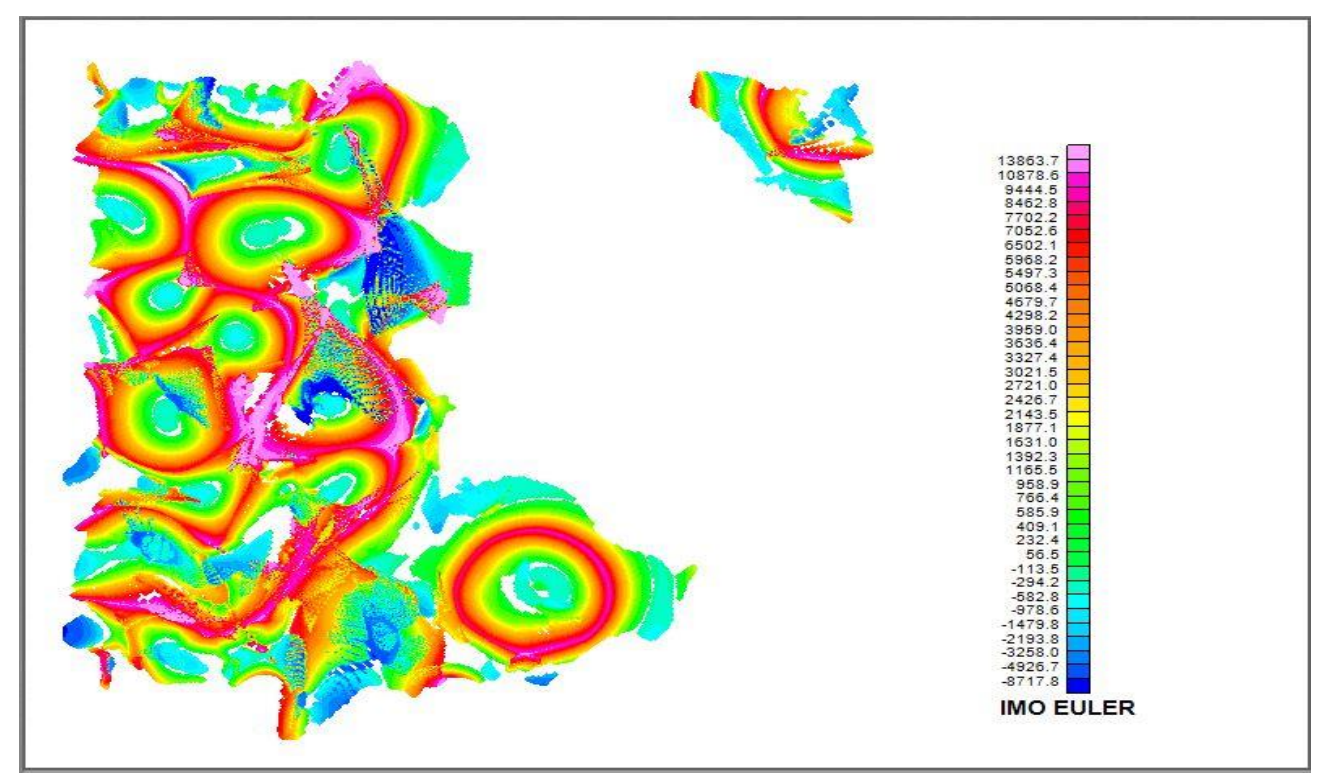

Fig.8. Euler depth map of Imo State from data analysis 


\section{Discussions}

The identified regions with gravity lows in the contour map (Fig. 2a) are made up of subsurface materials of low density values below those of the predicted models and unlike the regions with high gravity values above those of the predicted model that are composed of high density subsurface masses. The contour patterns are also indicative of syncline and anticline structures [18] which are confirmed by the model results. The model results show strike angles of varying degrees, meaning that the prevalent faulting system in the survey area is the strike-slip which are also known as a wrench, tear or trans-current faults. Hence we can infer that the faults are normal faults caused by extensional or tensional forces.

The depth to anomalous bodies range from 4,001 $\mathrm{m}$ to 9,439 $\mathrm{m}$, thus the anomalous bodies are mostly located in the Ameki and Imo Formations, while the density contrasts and model density used indicate the formations are composed of sandstones and shales. These are favorable environments for hydrocarbon habitation as is common in the Niger delta basin. The Euler depth estimates gave depth ranges of $113.5 \mathrm{~m}$ to 8,717 $\mathrm{m}$. These mean the sedimentary thickness in state range between these values and also represent the depth to basement in the region.

\section{Conclusion}

The results of the subsurface interpretations show that the region is composed of low and high density subsurface masses identified as syncline, anticline and faulted bodies. The density values of formations suggest sediments favorable to formation and hosting of hydrocarbon as is in the Niger delta basin. The sedimentary thickness of the state is also thick enough for hydrocarbon formation as is in other parts of the Niger delta. The maximum basement depth in the state from the study is $8,717 \mathrm{~m}$.

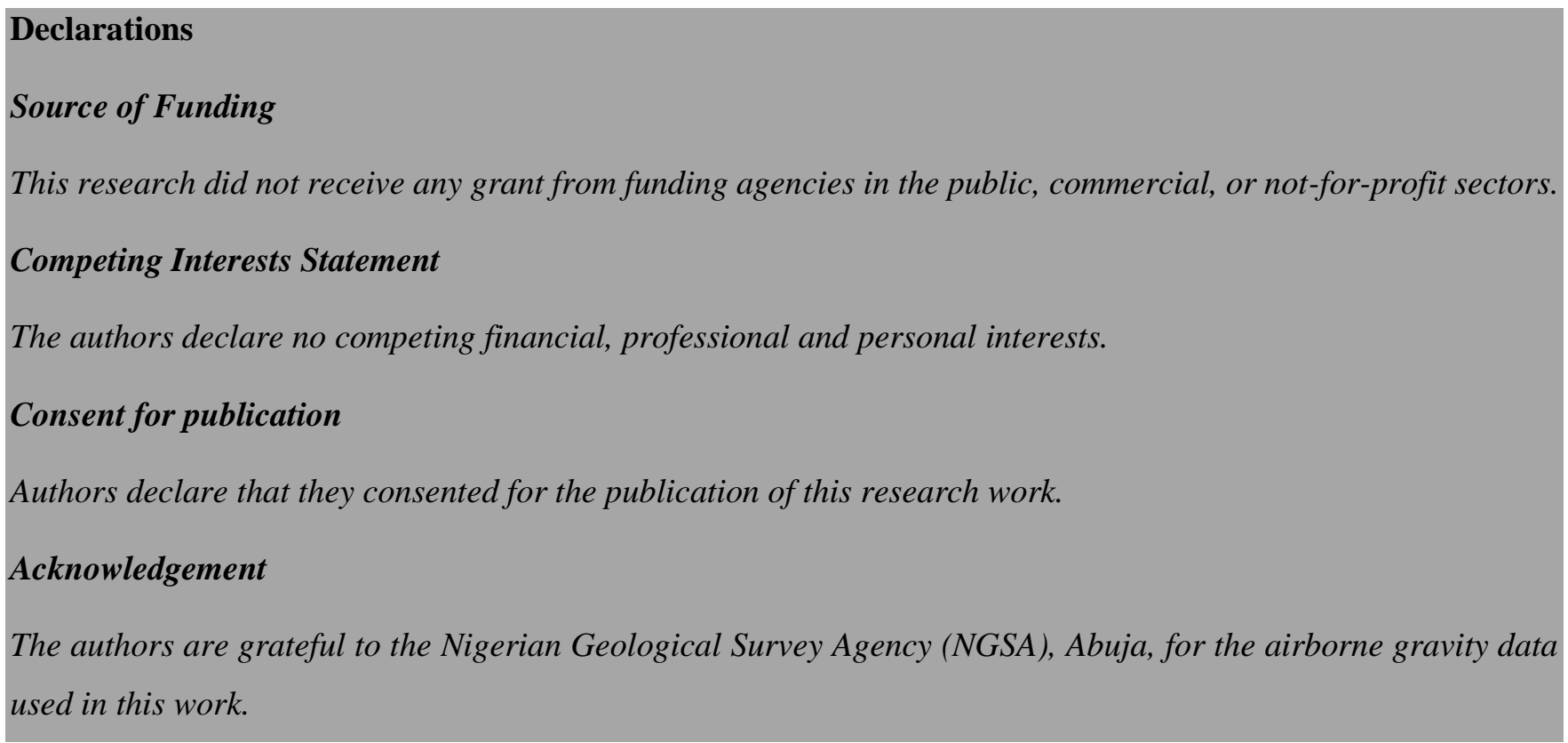

\section{References}

[1] Obaje, N. G. (2009). Geology and mineral resources of Nigeria. Springer-Verlag Berlin Heidelberg Publications. 
[2] Eke, P.O., Okeke, F.N. and Ezema, P.O. (2016). Improving the geological understanding of the Niger Delta basin of Nigeria using airborne gravity data. International Journal of Geography and Geology, 5(5), 97-103. U.S. Energy Information Administration, International Energy Statistics database, accessed 2/5/2020.

[3] Lowrie, W. and Fichtne, A. (2020). Fundamentals of Geophysics. Cambridge University Press; 3rd edition.

[4] Biswas, A and Sharma, S. P. (2020). Advances in Modeling and Interpretation in Near Surface Geophysics, Springer; 1 st Ed.

[5] Mishra, D.C. Principles, (2011). Gravity and Magnetic Methods for Geological Studies; Principles, Integrated Exploration and Plate Tectonics, CRC Press, Taylor and Francis Group.

[6] Fairhead, J.D. (2015). Advances in Gravity and Magnetic Processing and Interpretation, Eagle Publication Netherlands.

[7] Nigerian National Petroleum Corporation, NNPC, (2021). Oil Production, https://www.nnpcgroup.com Accessed 15/10/2021.

[8] Onyinye, O.S. and Obi, G.C. (2011). Sequence Stratigraphic Framework of the Imo Formation in the Southern Benue Trough, Journal of Mining and Geology, 47(2) 2011, 135-146.

[9] Ahiarakwem, C.A.A. and Onyekuru, S.O. (2011). A Comparative Assessment of the Physico-Chemical and Microbial Trends in Njaba River, Niger Delta Basin, Southeastern Nigeria, Journal of Water Resource and Protection, 3, 686-693.

[10] Eke, P.O and Ekpelu, G. (2021). Detection of shallow aquifers using vertical electrical sounding in Abua town, Rivers State Nigeria. Asian Journal of Basic Science and Research, 3(2), 95-101.

[11] Kamayou, V.M., Ehirim, C.N. and Ikiensikimama, S.S. (2021). Estimating Volume of Shale in a Clastic Niger Delta Reservoir from Well Logs: A Comparative Study. International Journal of Geosciences, 12, 949-959.

[12] Nwajide, C. S., 1979. A lithostratigraphic analysis of the Nanka Sands, south- eastern Nigeria. Journal of Mining and Geology, 16, 103-109.

[13] Ali, A., Hossein, N. AND Omid, O. (2013). Application of least squares and Euler deconvolution for solving inverse problems and locating the source of potential field. Global Journal of Science, Engineering and Technology, 14, 149-156.

[14] Li and Gotze, H. (1999). Comparison of some gridding methods. The leading Edge, 18, 898-900.

[15] Smith, Wessel, P. (1990). Gridding with continuous curvature splines in tension. Geophysics, 55(3), 293-305.

[16] Montaj Geophysics How-To Guide (2013). Applying filters with Montaj geophysics, www.geosoft.com.

[17] Reid, A.B., Allsop, J.M., Grauser, H., Millet, A.J. and Somerton, I.N. (1990). Magnetic interpretation in three dimension using Euler deconvolution, Geophysics, 55(1), 80-91.

[18] Prieto, C. (1996). Gravity/magnetic signatures of various geologic models-an exercise in pattern recognition. IGC footnote series, 4(4), 1-24. 